\title{
Lezen van studieboeken
}

Is er nog plaats voor studieboeken in derde millenium? Zijn wij, na eeuwen waarin het boek de mondelinge kennisoverdracht bijna heeft vervangen, niet op weg naar technologieën die het boek overbodig, onhandig en duur maken? En is stampen, repeteren en memoriseren nog wel of niet meer van deze tijd? Natuurlijk, we beschikken over bibliotheken vol naslagwerken, tijdschriftartikelen en talloze bronnen online voor het opzoeken van feiten, meningen, richtlijnen en achtergronden. Maar is opzoeken wel hetzelfde als leren? De tijd dat we feitenkennis onbelangrijk vonden, lijkt wat achter ons te raken. Immers, zonder georganiseerde kennis kunnen we geen problemen oplossen. ${ }^{1}$ Dat is nog geen pleidooi voor blind leren, maar de uitspraak "het gaat ons niet om feitenkennis maar alleen om inzicht" heeft iets kunstmatigs. Een hogere cognitieve vaardigheid toetsen is natuurlijk prima, maar wees eerlijk en zeg erbij dat de - lagere feitenkennis daarvoor nodig is. Wij zijn bij studieopdrachten niet altijd even helder naar studenten. Enerzijds moet de student leren kritisch te lezen, leren dat niet alles wat geschreven staat waar is en leren te interpreteren. Dat blijkt lastig genoeg. ${ }^{2}$ Anderzijds stellen we vaak studieboeken 'verplicht', bij voorkeur boeken die we als docent zelf geschreven hebben. Wat denkt u? Zou het 'kritisch lezen' dan niet eerder gaan over de vraag wat wel en wat niet bij de toets gevraagd zal worden? En wie neemt het studenten kwalijk dat zij 'ouderwets' leren? Studenten moeten immers eerst een referentiekader van feiten en inzichten opbouwen voordat zij daar nieu- we beweringen tegen kunnen afzetten, en onderwijs heeft een taak om dit referentiekader te helpen vormen. Dat neemt niet weg dat 'verplichte stof' een ambivalente aanduiding is. Aan de University of Southern California kregen in 1990/91 de tweedejaars geneeskundestudenten uit 33 boeken 10.997 verplichte en 11.161 aanbevolen pagina's tekst op. Hiervoor was 42 tot 71 uur leestijd per week nodig. Navraag bij 72 studenten leerde dat men gemiddeld 6 uur per week las (range 0-15 uur). 'Required reading lists are scarcely worth the paper they are written on' was de conclusie. 3 Waarom maken we niet duidelijker welke kennis we zullen beoordelen? Dan kunnen we ons beperken tot literatuursuggesties. Natuurlijk horen daar studieboeken bij. Ze vormen nog altijd het favoriete studiemedium en zijn 'studeerbaarder' dan een beeldscherm. Maar met de enorme toename van keuzemogelijkheden gaat het wel steeds meer om de vraag: hoe verlagen we de kwantiteit en verhogen we de kwaliteit van informatie? Hoe bepalen we wat kaf is en wat koren? Om daarin te helpen start TMO met een serie systematische, vergelijkende beoordelingen van studiemateriaal. We stellen ons ten doel in een jaar of vijf alle belangrijke disciplines de revue te laten passeren, met hulp van interfacultaire groepen die de redactie hiertoe uitnodigt. Wij zijn vereerd dat mw. dr F.M.M. Griffioen met andere ervaren docenten in het vakgebied van de anatomie en embryologie in dit nummer de spits wil afbijten.

Th.J. ten Cate 


\section{Literatuur}

1. Norman GR. Problem-solving skills, solving problems and problem-based learning. Med Educ 1988;22:279-86.

2. Stam J, Hommes DW, Does MC van der, Cate ThJ ten, Büller HR. Kunnen bijna afgestudeerde artsen hun vakliteratuur interpreteren? Ned Tijdschr Geneeskd 1990;134(17):854-7.

3. Taylor CR. The reading habits of year II medical students. New Eng J Med 1992;326(21):1436-40. 